\title{
Probiotic Characteristics and Anti-inflammatory Properties of an Indian Indigenous Lactobacillus plantarum against Pathogenic Salmonella Typhimurium
}

\author{
Projoyita Samanta ${ }^{1}$, V Deepak Bamola ${ }^{1}$, Bimal Das ${ }^{1}$, Parthoprasad Chattopadhyay ${ }^{2}$, Rama \\ Chaudhry ${ }^{1 *}$ \\ ${ }^{1}$ Department of Microbiology, ${ }^{2}$ Department of Biochemistry \\ All India Institute of Medical Sciences, New Delhi, India \\ *Corresponding author: Prof. Rama Chaudhry, Email: drramach@gmail.com
}

Running title: Probiotic Characteristics and Anti-inflammatory Properties of $L$ plantarum

\begin{abstract}
Probiotic should be well characterized for any preventive and therapeutic application. Studies have reported that the population specific indigenous probiotics are more effective. Huge number of probiotics are available globally but indigenous Indian probiotic candidates are limited. Therefore, a study was conducted to evaluate probiotic characteristics and antiinflammatory properties of an Indian indigenous Lactobacillus plantarum (Lp1) - (NCBI accession no- MN386242) against gastrointestinal (GI) pathogen Salmonella Typhimurium (ST) using Caco-2 cell lines. Anti-inflammatory properties were assessed by evaluating the expression of Immunoglobulins (IgA, IgG) receptors, Toll Like Receptors (TLR2, TLR4) and cytokine (IL10, IL-8, IL17 and IL23) using flowcytometry and Real Time-PCR. Lp1 showed good adhesion and ability to survive in high acidic and bile conditions of the gut. Lp1 demonstrated antagonistic potential against GI pathogens and modulated pro and antiinflammatory cytokines expression significantly. Observed result indicated that this indigenous Lp1 is a good probiotic candidate with anti-inflammatory potential and can be evaluated further clinically for the treatment or prevention of salmonellosis and other GI inflammatory disorders.
\end{abstract} Keywords: Probiotic, Lactobacillus, Cytokines, Salmonella Typhimurium 


\section{Introduction}

The human microbiome that acquired during and after birth is a major determinant of human health ${ }^{1}$ and play an important role in the human physiology, development, immunity and tolerance ${ }^{2}$. The concept of microbial intervention through probiotics ${ }^{3}$ in human body for health benefits has gained significant importance in the last few decades ${ }^{2}$. Probiotics have been shown to alter the gastrointestinal microflora, prevent translocation and overgrowth of enteric pathogens. The probiotics also improves the immune function, reduces lipid and cholesterol level and exhibits anti-allergic, anticancer and anti-oxidative effects ${ }^{4}$. Therefore, they are used to prevent and treat various lifestyle and gastrointestinal (GI) diseases but the health effects of probiotic are strain-specific. An effective probiotic strain should be safe, have originated from human, able to adhere and colonize the human gut, should resist degradation by hydrochloric acid, bile, pancreatic enzymes, have reduced intestinal permeability, should be able to antagonize pathogenic bacteria ${ }^{5-7}$. Probiotics are among the potential alternatives to combat the global challenge of antimicrobial resistance (AMR).

Lactobacilli are the potential probiotic candidate because of their beneficial and protective effects on health and generally regarded as safe (GRAS) status. L. plantarum is considered as one of the most significant Lactobacilli because of its distinctive probiotic properties ${ }^{8}$ and its antagonistic activity against intestinal pathogens ${ }^{9,10}$. L. plantarum attenuates intestinal inflammation ${ }^{11}$, modulates chronic inflammation and promotes human health. A symbiotic combination of $L$. plantarum effectively treated sepsis and lower respiratory tract infections in infants ${ }^{12}$. Immuno-modulatory effects of probiotics mediate through toll like receptors (TLRs) which recognizes microbe-associated molecular patterns (MAMPS) of the bacterial cells and trigger the host immune system. TLRs are involved in the modulation for intestinal inflammation and can activate signalling that results into cytokines production ${ }^{13}$.

Several studies have reported the significant differences in the gut microbiome of geographical diverse population due to the difference in diets and lifestyles and that support the use of locally sourced probiotics to achieve best health benefits ${ }^{14}$. Despite the fact that the probiotic market is blooming across the globe, the indigenous Indian probiotic strains are limited. Therefore, it is important to isolate and evaluate indigenous Indian probiotic candidates with proven targeted functional properties and thus, a study was conducted to isolate and evaluate probiotic and anti-inflammatory properties of an indigenous L. plantarum (Lp1) against GI pathogen Salmonella enterica serovar Typhimurium. 


\section{Material and Methods}

The study was carried out at All India Institute of Medical Sciences (AIIMS), New Delhi, India with ethical approval (ref no: IECS/T-13401-04-2015). Healthy subjects were enrolled in the study as per inclusion and exclusion criterion. A written consent was obtained from each enrolled subject to participate in the study.

Collection of samples, isolation and purification of Lactobacilli: Fresh stool samples were taken from the subject and processed for Lactobacillus isolation. A loop full of sample was inoculated into De Mann Rogosa and Sharpe (MRS) medium and incubated anaerobically for $48 \mathrm{~h}$ at $37^{\circ} \mathrm{C}$ for isolation of Lactobacillus. Only gram positive, non-spore forming, catalase negative isolates from MRS plates were further identified using API 50 CHL (Biomeruex, USA). Molecular identification of Lactobacillus was done by genus specific16S rRNA PCR 15. The identification was confirmed by amplification and sequencing of $1.5 \mathrm{~kb}$ region of 16 rRNA and the indigenous Lactobacillus strain used for this study was identified as Lactobacillus plantarum and named as Lp1 for in house use. The sequences of the strain Lp1 were submitted to NCBI gene bank (Accession no: MN386242).

\section{Screening of Probiotic Properties of Lactobacillus Isolates}

- Acid tolerance: Sterile MRS Broth was adjusted to $\mathrm{pH} 2.0, \mathrm{pH} 3.0$, and $\mathrm{pH} 6.4$ (as control) using $1.0 \mathrm{M} \mathrm{HCl}$. Test tubes containing $9 \mathrm{ml}$ of MRS broth at each $\mathrm{pH}$ were inoculated with $1.0 \mathrm{ml}\left(1 \mathrm{X} 10^{9} \mathrm{CFU} / \mathrm{ml}\right)$ of $\mathrm{Lp} 1$ cultures and incubated at $37^{\circ} \mathrm{C}$ for 3 hours. After incubation, $1.0 \mathrm{ml}$ of culture was serially diluted using $0.85 \%$ saline solution. The viable colonies was counted by plate count method ${ }^{16}$. The known probiotic strain (L. plantarum - ATCC202195) was used as a control.

- Bile tolerance: Bile tolerance was estimated on MRS broth supplemented with $0 \%$ (control), $0.5 \%$ and $1 \%$ bile salts by standard method ${ }^{16}$. Each experiment was done in triplicate.

- Bile Salt Hydrolase Activity: Bile salt hydrolase $(B s h)$ activity was assayed by direct plate method using sodium taurodeoxycholate (TDCA) ${ }^{17}$. Each experiment was performed in triplicate.

- Antibiotic Susceptibility: Antibiotic susceptibility of Lp1 was performed by disc diffusion method against commonly used antibiotics including -gentamicin, vancomycin, chloramphenicol, clindamycin, ampicillin, erythromycin and penicillin as per standard methods ${ }^{18}$. The result of the disc diffusion test was interpreted by according to CLSI 2015. 
The zone of inhibition around the antibiotic less than or equal to 14 is considered as resistant, zone of inhibition between 15 to19 are intermediate and zone of inhibition more than and equal to 20 are sensitive.

- Antagonistic Activity: Antagonistic activity of Lp1 was tested against, Salmonella Typhimurium, by well diffusion assay ${ }^{19}$. The diameter of the clear zone excluding the diameter of $6 \mathrm{~mm}$ well was scored as no inhibition - (negative), diameter 0 - $3 \mathrm{~mm}$ (weak); diameter 3-6 mm - (good) and diameter $>6 \mathrm{~mm}-$ (strong). Each experiment was performed in triplicate.

- Cell culture. Human colorectal adenocarcinoma cell line (Caco-2 cells) was procured from National Centre for Cell Sciences, Pune, India and maintained in an incubator at $37^{\circ} \mathrm{C}, 5 \%$ CO2, in Dulbecco's modified Eagle's minimal essential medium (DMEM, high clone, USA) (high glucose) supplemented with 10\% heat-inactivated foetal bovine serum (FBS) (Hyclone, USA), $10 \mathrm{mg} / \mathrm{ml}$ streptomycin, and10 U/ml penicillin. The Caco-2 cells $\left(1 \mathrm{X} 10^{5}\right.$ cells/well) were allowed to attach and grow in 6 and 12 well culture plates (Corning). The culture medium was changed every alternate day for 15 to 20 days until the cells were fully differentiation. Subsequently, these Caco-2 cells were used in different experiments conducted in this study.

- Adhesion assay: Adhesion to intestinal cell line was evaluated on Caco-2 cell line using standard method ${ }^{20}$. The results were expressed as percent adhesion and the ratio between adherent bacteria and initial inoculums of bacteria ${ }^{20}$.

- Cell surface hydrophobicity: The ell surface hydrophobicity was evaluated by the microbial adhesion to hydrocarbons (MATH) using xylene. The surface hydrophobicity (\%) was calculated using absorption at $600 \mathrm{~nm}$ at $0 \mathrm{~h}\left(\mathrm{~A}_{0}\right)$ and $1 \mathrm{~h}\left(\mathrm{~A}_{1}\right)$ using the formula described previously $\{\mathrm{H} \%=(1-\mathrm{A} 1 / \mathrm{A} 0) \mathrm{X} 100\}^{16}$.

- Cell Auto-Aggregation: The auto-aggregation assay was performed as per method described by Ren et al., 2014 and percentage was expressed as $(1-\mathrm{A} 1 / \mathrm{A} 0) \times 100^{16,21}$.

- Co-Aggregation of Lactobacilli and S Typhimurium: Equal quantity of (1 mL) Lp1 and $\mathrm{S}$ Typhimurium (pathogenic strain) were thoroughly mixed and incubated at $37^{\circ} \mathrm{C}$ without agitation. The absorbance of the mixtures was taken at $\mathrm{A}_{600 \mathrm{~nm}}$ at different time intervals $(0$ or $5 \mathrm{~h}$ ). Absorbance was recorded for the mixture and for the suspensions individually. Coaggregation was calculated as follows: $\left\{\left[\left(\mathrm{A}_{S T}+\mathrm{A}_{\mathrm{Lp} 1}\right) / 2-\mathrm{A}_{\operatorname{mix}}\right] /\left(\mathrm{A}_{S T}+\mathrm{A}_{\mathrm{Lp} 1}\right) / 2\right\} \times 100$, where $\mathrm{A}_{\mathrm{ST}}$ and $\mathrm{A}_{\mathrm{Lp} 1}$ represent $\mathrm{A}_{600 \mathrm{~nm}}$ of the separate suspensions of $\mathrm{S}$ Typhimurium and $L$ plantarum $\mathrm{Lp} 1$ in control tubes and $\mathrm{A}_{\text {mix }}$ represents the absorbance of the mixed bacterial suspension at $5 \mathrm{~h}^{22,23}$. 
- Fibronectin-binding protein genes (fbp) and mucus-binding protein (mub) gene: The presence of $f b p$ and $m u b$ were detected by reported ${ }^{17}$ and designed species-specific primers. The primers sequences used in the study are given in the Table 1.

Table1: List of primers used in Polymerase Chain Reaction (PCR)

\begin{tabular}{|c|c|c|c|c|}
\hline \multicolumn{2}{|c|}{ Primer (5'-3') } & \multirow{2}{*}{$\begin{array}{l}\text { Product } \\
\text { size } \\
\text { (bp) }\end{array}$} & \multirow{2}{*}{$\begin{array}{l}\text { Annealing } \\
\text { temp. }\end{array}$} & \multirow{2}{*}{$\begin{array}{c}\text { Reference } \\
\\
15\end{array}$} \\
\hline $\begin{array}{l}\text { LbLMA-1R } \\
16 \mathrm{~S} \text { rRNA } \\
\text { (Lactobacillus genus specific) }\end{array}$ & $\begin{array}{l}\text { CTCAAAACTAAACA } \\
\text { AAGTTTC }\end{array}$ & & & \\
\hline $\begin{array}{l}\text { LbLMA-R-161 } \\
\text { 16S rRNA }\end{array}$ & $\begin{array}{l}\text { CTTGTACACACCGC } \\
\text { CCGTTCA }\end{array}$ & & & \\
\hline $\begin{array}{l}\text { fD1 } \\
\text { (16s rRNA universal primer) }\end{array}$ & $\begin{array}{l}\text { AGAGTTTGATCCTG } \\
\text { GCTCAG }\end{array}$ & 1,500 & $60^{\circ} \mathrm{C}$ & 24 \\
\hline $\mathrm{rP} 2$ & $\begin{array}{l}\text { ACGGCTACCTTGTT } \\
\text { ACGACTT }\end{array}$ & & & \\
\hline $\begin{array}{l}\text { LpMubD1F/R } \\
\text { MUB-domain of Mub protein }\end{array}$ & $\begin{array}{l}\text { ATGCGTATCGGACG } \\
\text { GCTGATAC }\end{array}$ & $\begin{array}{l}425, \\
1050\end{array}$ & $55^{\circ} \mathrm{C}$ & 17 \\
\hline $\begin{array}{l}\text { LpMubD1R } \\
\text { MUB-domain of Mub protein }\end{array}$ & $\begin{array}{l}\text { AACAGCCTCAAAAC } \\
\text { GACCAGTC }\end{array}$ & & & \\
\hline $\begin{array}{l}\text { Lp FBPF } \\
\text { Fibronectin binding protein }\end{array}$ & $\begin{array}{l}\text { GTCCTTTGATGGTTT } \\
\text { ATTTACCC }\end{array}$ & 1500 & $50^{\circ} \mathrm{C}$ & 17 \\
\hline $\begin{array}{l}\text { Lp FBPR } \\
\text { Fibronectin binding protein }\end{array}$ & $\begin{array}{l}\text { AGAAGTATGCGGCG } \\
\text { AGATTCGC }\end{array}$ & & & \\
\hline
\end{tabular}

\section{Immuno-modulatory effect of $L$ plantarum (Lp1) on Caco-2 cell line}

\section{Challenge with Salmonella Typhimurium (ST) (clinical isolate) along with Lp1 strain:}

Caco-2 cells (1X $10^{5}$ cells / mL) were seeded in 12-well plates for 15-20 days and confluent monolayer was used for the experiment. The cells were incubated with antibiotic free medium 1day before the experiment. The cells were washed and co-incubated with $1 \mathrm{ml}$ of Lp1 suspension ( $1 \times 10^{9} \mathrm{CFU} / \mathrm{ml}$ in antibiotic-free DMEM), $S$ Typhimurium $\left(1 \mathrm{X} 10^{8} \mathrm{cfu} / \mathrm{ml}\right)$ and both. After incubation for $4 \mathrm{~h}$ at $37^{\circ} \mathrm{C}$ under $5 \% \mathrm{CO} 2$, the bacteria were removed and the cells were washed thoroughly with sterile PBS and used for further experiments using standard protocol $^{25}$.

Immunoglobulin (IgA \& IgG) expression: The expression of $\operatorname{Ig} A$ and $\operatorname{IgG}$ on the surface of Caco- 2 cells was measured by standard flowcytometry method ${ }^{26}$.

TLRs and cytokines profiling of the treated Caco-2 cells: TLRs and cytokine expressions were studied at mRNA level by reported method ${ }^{27}$ using quantitative real-time polymerase chain reaction (qRT-PCR). The RNA extraction of the cells was carried out using Trizol. The RNA was treated with DNAse enzyme to remove any genomic DNA contamination. The 
quality and quantity of RNA was checked using Nanodrop. The synthesis of c-DNA from mRNA was done using c-DNA kit (BioRad, USA). The relative expression of TLR-2, TLR-4, and IL10, IL8, IL17 and IL23 mRNA was quantified by qRT-PCR using the SYBR Green PCR Master Mix and ABI-Step one plus Detection System (Applied Biosystems, USA). The PCR mixture consists of $12.5 \mu \mathrm{L}$ of Maxima SYBR Green Mastermix (thermo scientific), $0.5 \mu \mathrm{L}$ of each primer and $5 \mu \mathrm{L}$ of $\mathrm{c}$ DNA $(0.5 \mu \mathrm{g} / \mathrm{L})$ as the template. PCR water was used to adjust the final volume to $25 \mathrm{ml}$. The initial denaturation at $95^{\circ} \mathrm{C}$ for 1 minute was followed by 40 cycles of denaturation at $95^{\circ} \mathrm{C}$ for 30 seconds, annealing at suitable temperature (Table 2) for 30 seconds, and extension at $72^{\circ} \mathrm{C}$ for 40 seconds. Glyceraldehyde-3-phosphate dehydrogenase (GAPDH, housekeeping gene) was amplified as the internal standard ${ }^{25}$. The following equation was used to analyse the data:

Relative expression of $\mathrm{mRNA}=2^{-\Delta \Delta C t}($ Where $\mathrm{Ct}=$ threshold cycle, $\Delta \mathrm{Ct}=\mathrm{Ct}$ target gene Ct GAPDH, $\Delta \Delta \mathbf{C t}=\Delta \mathrm{Ct}$ treated- $\Delta \mathrm{Ct}$ untreated $)^{28}$

Statistical analysis: All of the tests were performed in triplicates and the results were presented as mean \pm SD. All the statistical analysis was performed using SPSS Version 16.

The Kruskal-Walis test, followed by post hoc LSD test, were used to determine statistical significance.

Table 2: List of primers used in RT- qPCR for relative quantification of following genes

\begin{tabular}{|c|c|c|c|c|c|}
\hline \multicolumn{2}{|r|}{ Primer $\left(5^{\prime}-3^{\prime}\right)$} & \multirow{2}{*}{$\begin{array}{l}\begin{array}{l}\text { Product } \\
\text { size }\end{array} \\
183 \mathrm{bp}\end{array}$} & \multirow{2}{*}{$\begin{array}{l}\text { Annea } \\
\text { ling } \\
\text { temp. } \\
58^{\circ} \mathrm{C}\end{array}$} & \multirow{2}{*}{$\begin{array}{l}\text { Temp } \\
\left({ }^{\circ} \mathrm{C}\right) \\
78.3^{\circ} \mathrm{C}\end{array}$} & \multirow{3}{*}{$\begin{array}{l}\text { Reference } \\
\text { Designed } \\
\text { for this } \\
\text { study }\end{array}$} \\
\hline $\begin{array}{l}\text { IL } 8 \\
\text { forward }\end{array}$ & TCTGGACCCCAAGGAAAC & & & & \\
\hline $\begin{array}{l}\text { IL8 } \\
\text { reverse }\end{array}$ & CATCTGGCAACCCTACAACA & & & & \\
\hline $\begin{array}{l}\text { IL10 } \\
\text { forward }\end{array}$ & AAA GAA GGC ATG CAC AGC TC & $132 \mathrm{bp}$ & $60^{\circ} \mathrm{C}$ & $90^{\circ} \mathrm{C}$ & 29 \\
\hline $\begin{array}{l}\mathrm{IL} 10 \\
\text { reverse }\end{array}$ & AAG CAT GTT AGG CAG GTT GC & & & & \\
\hline $\begin{array}{l}\text { IL17 } \\
\text { forward }\end{array}$ & GGCTGGAGAAGATACTGGTGT & $171 \mathrm{bp}$ & $58^{\circ} \mathrm{C}$ & $84.6^{\circ} \mathrm{C}$ & $\begin{array}{l}\text { Designed } \\
\text { for this }\end{array}$ \\
\hline $\begin{array}{l}\mathrm{IL} 17 \\
\text { reverse }\end{array}$ & TTAGTCCGAAATGAGGCTGTCT & & & & study \\
\hline $\begin{array}{l}\text { IL } 23 \\
\text { forward }\end{array}$ & CTGAGGGAACCAAACCAGAG & 166bp & $58^{\circ} \mathrm{C}$ & $\begin{array}{l}83.04 \\
{ }^{\circ} \mathrm{C}\end{array}$ & $\begin{array}{l}\text { Designed } \\
\text { for this }\end{array}$ \\
\hline $\begin{array}{l}\text { IL } 23 \\
\text { reverse }\end{array}$ & GCAGCAACAGCAGCATTACA & & & & \\
\hline $\begin{array}{l}\text { GAPDH } \\
\text { forward }\end{array}$ & CAACGACCACTTTGTCAAGC & 140bp & $58^{\circ} \mathrm{C}$ & $82.8^{\circ} \mathrm{C}$ & 29 \\
\hline $\begin{array}{l}\text { GAPDH } \\
\text { reverse }\end{array}$ & TTCCTCTTGTGCTCTTGCTG & & & & \\
\hline
\end{tabular}




\begin{tabular}{|l|l|l|l|l|l|}
\hline $\begin{array}{l}\text { TLR2 } \\
\text { forward }\end{array}$ & GATGCCTACTGGGTGGAGAA & $159 \mathrm{bp}$ & $58^{\circ} \mathrm{C}$ & $79.2^{\circ} \mathrm{C}$ & $\begin{array}{l}\text { Designed } \\
\text { for this } \\
\text { study }\end{array}$ \\
\hline $\begin{array}{l}\text { TLR2 } \\
\text { reverse }\end{array}$ & GACGGAAATGGGAGAAGTCC & & & & \\
\hline $\begin{array}{l}\text { TLR4 } \\
\text { forward }\end{array}$ & CGGTCCTCAGTGTGCTTGTA & $220 \mathrm{bp}$ & $58^{\circ} \mathrm{C}$ & $82^{\circ} \mathrm{C}$ & $\begin{array}{l}\text { Designed } \\
\text { for this } \\
\text { study }\end{array}$ \\
\hline $\begin{array}{l}\text { TLR4 } \\
\text { reverse }\end{array}$ & TCCTTACCCAGTCCTCATCC & & & \\
\hline
\end{tabular}

\section{Results and Discussion}

Lactobacilli are generally regarded as safe (GRAS) and the most common probiotic candidates because of their beneficial and protective effects on health ${ }^{30}$. L. plantarum is one of the important Lactobacilli due to its distinctive probiotic properties ${ }^{8}$ and antagonistic activity against intestinal pathogens ${ }^{9,10}$. L. plantarum attenuates intestinal inflammation ${ }^{11}$, and promotes human health ${ }^{31,32}$. A symbiotic combination of $L$ plantarum effectively treated sepsis and lower respiratory tract infections in infants ${ }^{12}$. The aim of the present study was to evaluate the probiotic potential and anti-infective properties of Lactobacilli isolated from healthy Indians. For the selection of potential probiotic strain, species identification, evaluation of physio-chemical and functional properties of the strain are prerequisite (FAO/WHO2002). There are many phenotypic and genotypic tools available for the identification of Lactobacillus species including16S rRNA gene sequencing ${ }^{10}$.

In this study a total of 10 Lactobacilli were isolated from faecal samples of Indian healthy subjects. Strains were identified by phenotypic and genotypic methods and evaluated for their probiotic properties and the isolates were identified as Lactobacilli by 16S rRNA genus specific PCR. One strain which demonstrated good probiotic properties and effective against ST among others was confirmed by sequencing of $1.5 \mathrm{~kb}$ region of 16 rRNA and identified as Lactobacillus plantarum and named as Lp1 for in-house use. BLAST match of 16S rDNA sequences of the Lp1 strain showed 95\% homology with NCBI database and the sequences were submitted to NCBI (Gene bank accession no: MK723996). Carbohydrate fermentation of Lp1 was tested by API 50CH which showed the hetero-fermentative nature of this strain and that was in agreement with another study ${ }^{10}$. Lp1 utilised L-arabinose, ribose, D-glucose, D-galactose, D-mannose, D-fructose, lactose, mannitol, sorbitol, rhamnose, methyl- $\alpha \mathrm{D}$-Mannopyranoside, $\mathrm{N}$-acetyl-glucosamine, arbutine, amygdaline, esculin, salicine, cellobiose, maltose, melezitose, melibiose, gentiobiose, saccgarose, raffinose, trehalose and Dturanose Xylose, but methyl- $\beta \mathrm{D}$-xylopyranoside, methyl- $\alpha \mathrm{D}$-glucopyranoside variably. 
An effective probiotic strain should survive in the upper digestive tract to reach the large intestine and to be colonized in gut so that it can improve intestinal function and maintain the integrity of the lining of the intestines ${ }^{33}$. Therefore, acid and bile salt tolerance are important selection criteria for a probiotic strain and these properties are strain specific ${ }^{17,25}$. Bile salts play a vital role in the immune mechanism of the gut which is associated with carbohydrate fermentation, glycosidase activity ${ }^{34}$, exo-polysaccharide production ${ }^{32}$, facilitates adhesion of probiotics to mucin and prevents adhesion of pathogens ${ }^{32}$. In the present study Lactobacilli $\mathrm{Lp} 1$ showed best survival $(8.7 \pm 0.1 \mathrm{Log} \mathrm{cfu} / \mathrm{ml})$ rate at $\mathrm{pH} 2 \mathrm{for} 3 \mathrm{~h}$ similar to the control strain (L. plantarum ATCC-202195, 8.8 $\pm 0.04 \mathrm{Log} \mathrm{cfu} / \mathrm{ml}$ ). Other isolated Lactobacilli Lb3, Ldel4, Lb2, Lb5, Lp2 and Ldel1 showed poor survival at pH 2 with significant decrease in their viability $(\mathrm{p}<0.05)$ compared to the control strain. Lp1 showed good survival $(\geq 8 \log$ $\mathrm{CFU} / \mathrm{ml})$ similar to control strain $(8.83 \pm 0.2 \mathrm{Log} \mathrm{cfu} / \mathrm{ml})$ at $1 \%$ concentration of bile salt which was more than the physiological range $(0 \cdot 3$ to $0.5 \%)$ of human bile concentration (Mainville et al., 2005). Lp1 was tested positive for production of bile salt hydrolase (bsh) enzyme and was able to de conjugate the bile salt TDCA and precipitates forming a halo around the colony.

Table 3: Probiotic properties of Lactobacilli isolated from healthy human

\begin{tabular}{|c|c|c|c|c|c|c|c|c|}
\hline $\begin{array}{l}\text { SL. } \\
\text { no }\end{array}$ & Isolate & $\begin{array}{c}\text { Identification } \\
\text { (API) }\end{array}$ & $\begin{array}{c}\text { Initial } \\
\text { (Log } \\
\text { CFU/ml) } \\
\end{array}$ & $\begin{array}{c}\text { pH } 3(\mathrm{Log} \\
\text { CFU/ml) }\end{array}$ & $\begin{array}{l}\text { pH } 2(\mathrm{Log} \\
\text { CFU/ml) }\end{array}$ & $\begin{array}{l}\text { 0.5\% Bile } \\
\text { (Log } \\
\text { CFU/ml) }\end{array}$ & $\begin{array}{c}\text { 1\% Bile } \\
\text { (Log } \\
\text { CFU/ml) }\end{array}$ & $\begin{array}{c}\text { BSH } \\
\text { activity }\end{array}$ \\
\hline 1 & $\begin{array}{l}\text { L. plantarum - } \\
\text { ATCC-202195 }\end{array}$ & Control & $9 \pm 0.05$ & $9 \pm 0.2$ & $8.8 \pm 0.63$ & $8.9 \pm 0.87$ & $8.8 \pm 0.34$ & + \\
\hline 2 & Lp1 & L.plantarum & $9.1 \pm 0.3$ & $8.8 \pm 0.02$ & $8.8 \pm 0.3$ & $8.6 \pm 0.08$ & $8.7 \pm 0.67$ & + \\
\hline 3 & Lb1 & L.brevis & $9.2 \pm 0.03$ & $8.2 \pm 0.09$ & $8 \pm 0.05$ & $8.3 \pm 0.64$ & $8 \pm 0.07$ & - \\
\hline 4 & Ldel1 & L.delbrurkii & $9.05 \pm 0.2$ & NG & $\mathrm{NG}$ & $7.6 \pm 0.09$ & $4 \pm 0.88$ & - \\
\hline 5 & Lb2 & L.brevis & $9.0 \pm 0.5$ & $8.6 \pm 0.62$ & $8.6 \pm 0.72$ & $8.7 \pm 0.03$ & $8 \pm 0.59$ & - \\
\hline 6 & Lb3 & L.brevis & $8.8 \pm 0.4$ & $8.9 \pm 0.23$ & $8.7 \pm 1.92$ & $8 \pm 0.73$ & $8 \pm 0.07$ & - \\
\hline 7 & Ldel2 & L.delbrurkii & $8.9 \pm 0.3$ & $7 \pm 0.72$ & $5 \pm 0.67$ & $7.2 \pm 0.57$ & $7.1 \pm 0.08$ & - \\
\hline 8 & Lb4 & L.brevis & $9.5 \pm .073$ & $8.9 \pm 0.09$ & $8.7 \pm 0.62$ & $8.5 \pm 0.33$ & $8.5 \pm 0.93$ & - \\
\hline 9 & Lb5 & L.brevis & $9.06 \pm 0.2$ & $7.6 \pm 0.02$ & NG & $6.7 \pm 0.06$ & NG & - \\
\hline 10 & Ldel3 & L.delbrurkii & $8.9 \pm 0.03$ & $6 \pm-.08$ & NG & $7.2 \pm 0.32$ & NG & - \\
\hline 11 & Lp2 & L.plantarum & $9.1 \pm 0.1$ & $8 \pm 0.82$ & $7.4 \pm 0.21$ & NG & NG & - \\
\hline
\end{tabular}

Values are means of 3 replicates \pm SD.

*Significant difference $(P<0.05)$ among all Lactobacillus strains within the same column

Adhesion is another important characteristic of probiotics which prevent their elimination by peristaltic movement of intestine, helps in the competitive exclusion of enteropathogens ${ }^{22}$, stimulates immune system ${ }^{13}$ and promote antagonistic activity against enteropathogens ${ }^{25}$. Lp1 exhibited very good (14\%) adhesion to Caco-2 cells. The adhesion of Lp1 
was in the higher side of the range of adhesion (4-14\%) reported for other Lactobacillii strains tested in other studies ${ }^{17,25}$. Lp1 showed the presence of $m u b$ and $f b p$ genes involved in adhesion of bacteria to epithelial cells and that further supports the adhesion potential of the Lp1. Lp1 exhibited good hydrophobocity (43\%) and auto-aggregation of 38\%. Lp1 also exhibited good coaggregation with S Typhimurium $(27.23 \pm 1.57 \%)$ which was statistically significant $(\mathrm{p}$ value $=0.032)$

Table 4: Probiotic properties of Lactobacilli isolated from healthy human

\begin{tabular}{|c|c|c|c|c|c|c|c|}
\hline & Isolate & $\begin{array}{c}\text { Identificatio } \\
\text { n (API) }\end{array}$ & $\begin{array}{c}\text { Initial } \\
\text { (Log } \\
\text { CFU/ml) } \\
\end{array}$ & $\begin{array}{c}\text { Adhesion } \\
\text { (Log } \\
\text { CFU/ml) } \\
\end{array}$ & $\begin{array}{c}\text { Hydro- } \\
\text { Phobocity }(\%)\end{array}$ & $\begin{array}{c}\text { Auto- } \\
\text { aggregation } \\
(\%)\end{array}$ & $\begin{array}{c}\text { Co- } \\
\text { aggregation } \\
(\%) \\
\end{array}$ \\
\hline 1 & $\begin{array}{l}\text { L plantarum } \\
\text { ATCC- } \\
202195\end{array}$ & Control & $9 \pm 1.2$ & $7.9 \pm 0.04$ & $40.5 \pm 1.1$ & $32 \pm 1.3$ & $25 \pm 1.03$ \\
\hline 2 & Lp1 & L.plantarum & $9.4 \pm 0.82$ & $8.1 \pm 0.32$ & $43.6 \pm 0.91$ & $38.7 \pm 0.87$ & $27.23 \pm 1.57$ \\
\hline 3 & Lb1 & L.brevis & $8.7 \pm 2.1$ & $5.1 \pm 0.63$ & $2.4 \pm 3.1$ & $30.8 \pm 0.06$ & $23 \pm 0.93$ \\
\hline 4 & Ldel1 & L.delbrurkii & $9.05 \pm 1.6$ & $\mathrm{NG}$ & $5.2 \pm 0.92$ & $21 \pm 0.63$ & $11.04 \pm 0.64$ \\
\hline 5 & Lb2 & L.brevis & $9.0 \pm 0.08$ & $5.7 \pm 0.08$ & $13 \pm 0.07$ & $18.7 \pm 0.22$ & $18.03 \pm 1.03$ \\
\hline 6 & Lb3 & L.brevis & $9.2 \pm 0.07$ & $4.1 \pm 0.09$ & $1.3 \pm 0.72$ & $32.08 \pm 2.1$ & $21 \pm 0.32$ \\
\hline 7 & Ldel2 & L.delbrurkii & $8.9 \pm 0.09$ & $\mathrm{NG}$ & $11 \pm 0.59$ & $18 \pm 1.09$ & $9.32 \pm 2.1$ \\
\hline 8 & Lb4 & L.brevis & $9.2 \pm 0.91$ & $3.3 \pm 0.24$ & $26.06 \pm 1.9$ & $25.9 \pm 0.82$ & $24.42 \pm 1.1$ \\
\hline 9 & Lb5 & L.brevis & $8.6 \pm 2.1$ & $\mathrm{NG}$ & $12 \pm 1.5$ & $8.63 \pm 0.99$ & $10.2 \pm .92$ \\
\hline 10 & Ldel3 & L.delbrurkii & $8.9 \pm 1.2$ & NG & $13 \pm 0.39$ & $16.93 \pm 0.03$ & $12.84 \pm 0.43$ \\
\hline 11 & Lp2 & L.plantarum & $9.01 \pm 0.3$ & NG & $18 \pm 1.92$ & $8.63 \pm 0.73$ & $8.1 \pm 0.09$ \\
\hline
\end{tabular}

The knowledge of the antibiotic resistant phenotypes is important and the resistance genes should not be present in the Lactobacilli. The Lactobacilli commonly exhibits intrinsic resistance to various classes of antibiotics, which can be advantageous for their use in the prevention and treatment of various gastrointestinal infections. AST of the Lp1 showed that the strain was sensitive to common antibiotics including penicillin, erythromycin, imipenem clindamycin, Chloramphenicol, ciprofloxacin, amikacin, amoxiclav and gentamycin. Lp1 was found resistant to metronidazole and vancomycin. Previous studies reported that Lactobacilli are commonly resistant to vancomycin and metronidazole ${ }^{35,36}$. Studies reported that Lactobacilli exhibit high resistance to aminoglycosides ${ }^{35,37}$, variable resistance to chloramphenicol and erythromycin ${ }^{38-41}$ and generally susceptible to cephalosporins ${ }^{40,42}$.

Salmonella Typhimurium (ST) is a gram negative enteric pathogen ${ }^{43}$ which enters human gut through consumption of contaminated food or drink. An increase in antibiotic resistance strains of ST raised the concern and developed the need to find alternative prophylactic and therapeutic agents to control this important gastrointestinal pathogen ${ }^{44-46} . S$. 
Typhimurium adheres to the host GI epithelial cells, invades and disrupts the GI epithelial integrity and activates host innate immune response through cell signal pathways such as Toll Like Receptors, TLRs ${ }^{14}$ or nucleotide-binding oligomerization domain-(NOD)-like receptors (NLRs) of gastrointestinal epithelium identify pathogen associated molecular patterns (PAMPs) on ST leading to inflammation of the gut ${ }^{47}$. Isolated Lactobacilli in our study exhibit broad range antagonistic activity against both gram negative and gram-positive pathogens. Lp1 inhibited all the target organisms exhibited strong antagonistic activity against $S$. Typhimurium (5.6 \pm 01.4). Other Lactobacilli showed less inhibition against the target organisms as compared to Lp1. Observed results indicated that Lp1 is a good probiotic candidate, which may be tested and used to treat targeted infections and antibiotic resistance. Other studies also reported that L. plantarum found to inhibit $S$. Typhimurium ${ }^{21}$, sepsis and lower respiratory tract infections in infants ${ }^{12}$.

Secretory $\operatorname{Ig} \mathrm{A}$ is present in high concentrations in the lumen of the intestine. There it plays a pivotal role in trapping pathogenic bacteria in the mucus layer, thereby preventing infection ${ }^{48}$. Lp1 significantly increases the expression of IgA receptors in Caco-2 cells when co-stimulated with S. Typhimurium as compared to control (untreated Caco-2 cells). The Lp1 increases the expression of $\operatorname{IgA}$ receptors to $20.92 \pm 1.44 \%$ and $23.90 \pm 0.97 \%$ respectively when treated alone and co-stimulated with $S$. Typhimurium and the expression was significant $(\mathrm{p}=0.0035$,) as compared to control. While the expression of IgA receptors in control (untreated Caco-2 cells) was $9.44 \pm 2.01 \%$. IgA reduces the motility and virulence of pathogenic microorganism such as Salmonella by altering the expression of flagellin that compromises its motility ${ }^{49}$. IgA shields epithelial cells against the harmful effects of bacterial toxins by neutralising them ${ }^{50,51}$. The Lp1 increases the expression of IgG receptors to $1.77 \pm 0.35 \%$ and $0.99 \pm 0.23$ respectively when treated alone and co-stimulated with S. Typhimurium although the increase was not statistically significant as compared to the control $(0.74 \pm 0.25 \%)$. Other studies also reported that $\mathrm{IgG}$ are generally present in very low concentration in the GI lumen, imparts immunity to the host against infection ${ }^{52}$.

Lp1 up-regulated the expression of TLR2 by $8.21 \pm 0.95$ folds as compared to control when treated alone. Co-stimulation of Lp1 with S. Typhimurium up-regulated the expression of TLR2 to $7.68 \pm 0.72$ folds as compared to control. Lp1 up-regulated the expression of TLR4 by $1.52 \pm 0.26$ folds while $S$ Typhimurium stimulated cells, up-regulated the expression of TLR4 by $13.35 \pm 0.70$ folds. Lp1 altered the expression of TLR4 by $24.99 \pm 0.55$ folds when co stimulated with $S$ Typhimurium which indicated Lp1 was able to increase TLR4 expression significantly $(\mathrm{p}=0.00065)$. Studies have reported that TLR 2 is activated by probiotic bacteria 
and their fermented biogenic components ${ }^{52}$. A study showed that there was significant increase in TLR2 expression in $S$ Typhimurium infected mice when treated with $L$ plantarum MTCC5690 ${ }^{53}$.

Lp1 was able to increase expression of IL-10 (anti-inflammatory cytokine) significantly $(\mathrm{p}=0.001)$ and decrease the expression of IL-8, IL-17 and IL-23 (proinflammatory cytokines $)$ significantly $(\mathrm{p}=0.03,0.00043,0.0043)$ even in challenged environment induced by $S$. Typhimurium $(P<0.001)$. The anti-inflammatory potential of Lp1, which was in agreement with the reports that probiotics may protect intestinal epithelial cells from entero-pathogens by inhibiting IL-8 production ${ }^{54}$. IL23 are important for Th17 cell expansion, stabilization, and conditioning for a fully inflammatory cell phenotype ${ }^{55,56}$. The cytokine IL-23 is primarily associated with host innate immune responses against Salmonella. It induces the production of IL- 17 and IL-22, which results in the prompt response against the pathogens ${ }^{57}$. A study showed that L plantarum ZS2058 strongly promotes the IL-23/IL-17 axis whereas LGG significantly reduced the TNF-a levels in the colon while maintaining IL$10^{58}$. Our findings were consistent with other studies ${ }^{25,59}$. S Typhimurium infection upregulated the expression of IL23 and IL17 which plays an important role in the inflammatory response of the intestine ${ }^{58}$.

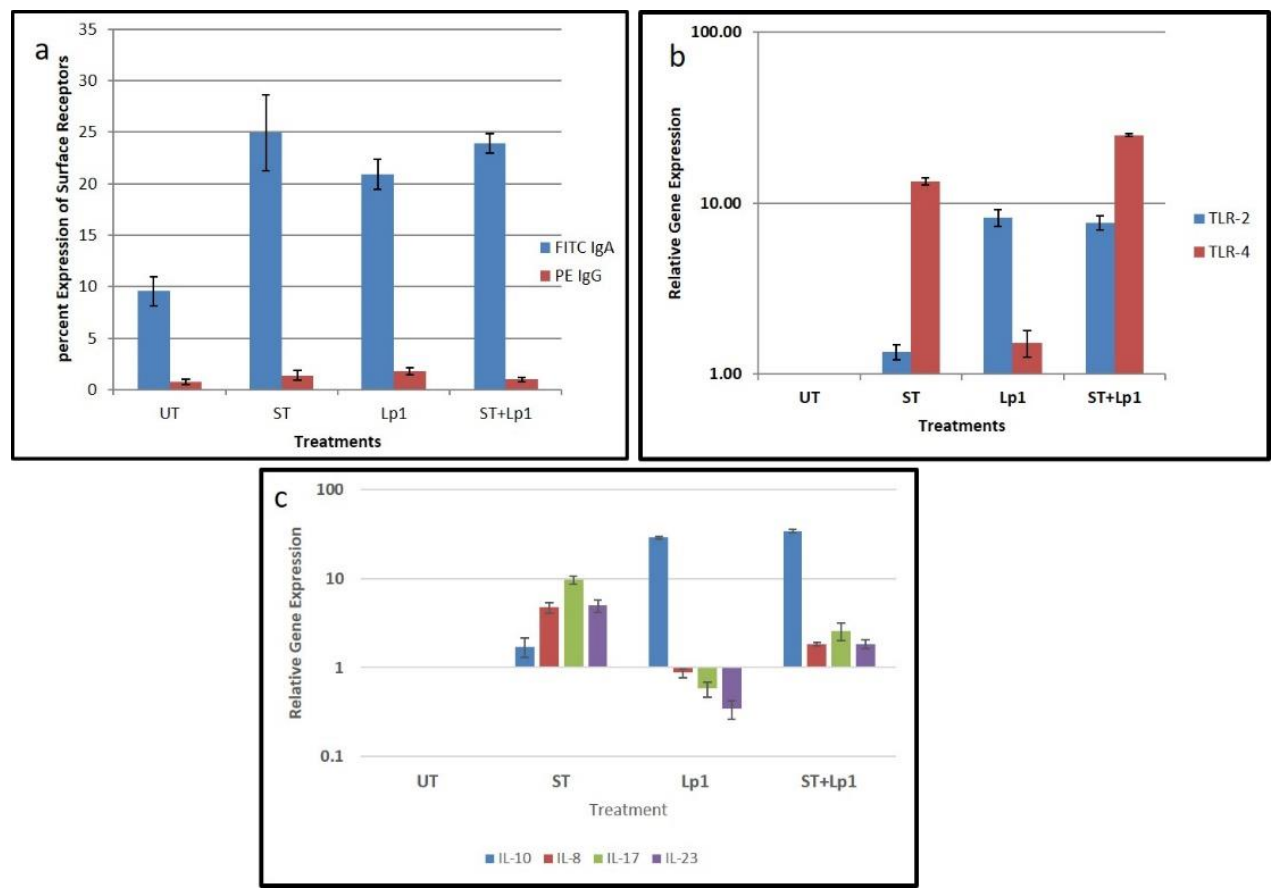

Figure 2: a) IgA and IgG expression on Caco-2 cell line by L. plantarum (Lp1); b) TLR2 and TLR4 expressions on Caco- 2 cell line by Lp1; c) expressions of anti and pro inflammatory cytokines on Caco-2 cell line by Lp1 
Clinical salmonellosis commonly treated with extended-spectrum antibiotics which may lead to antibiotic resistance and gut dysbiosis. The emergence of anti-microbial resistance (AMR) is a global issue that makes the treatment challenging for various infections including $S$ Typhimurium. An increase in MDR S Typhimurium necessitates an urgent alternative approach. Probiotics are a promising substitute to antibiotics in various gastrointestinal diseases including $S$ Typhimurium infection ${ }^{60}$. They are able to directly inhibit growth of $S$ Typhimurium by competing for nutrient sources, producing antimicrobial peptide, colonization resistance, increasing epithelial tight junction and increasing the expression and production of both SIgA and anti-inflammatory cytokine against $S$ Typhimurium ${ }^{61,62}$. The observed results indicated that Lp1 have antagonistic and anti-inflammatory potential and can be evaluated for the management of GI inflammatory disorders and $S$ Typhimurium infection.

\section{Conclusion}

Lactobacillus plantarum (Lp1) possess good probiotic properties which showed good survival in high acidic and bile conditions of the human gut without losing the viability. Lp1 indicated significant antagonistic effect against GI pathogens $S$. Typhimurium and showed promising immuno-modulatory potential by inhibiting the expression of pro-inflammatory cytokines and enhancing the expression of anti-inflammatory cytokines even in the challenged environment with $S$. Typhimurium induced Caco-2 cell line. The strain also demonstrated immunogenic potential by inducing significant up regulation of TLR-2 and IgA receptors expression even in challenged Caco-2 cells induced by $S$. Typhimurium. Therefore, the findings of the study strongly support that the Lp1 is a good probiotic candidate which can be evaluated further for the prevention and treatment of $S$ Typhimurium infection, and GI inflammatory conditions.

Conflict of interest: All the authors declared no conflict of interest 


\section{References}

1. Bengmark S. Pre-, pro- and synbiotics. Curr Opin Clin Nutr Metab Care 2001; 4: 571579.

2. Hardy H, Harris J, Lyon E, et al. Probiotics, Prebiotics and Immunomodulation of Gut Mucosal Defences: Homeostasis and Immunopathology. Nutrients 2013; 5: 1869-1912.

3. Hill C, Guarner F, Reid G, et al. Expert consensus document. The International Scientific Association for Probiotics and Prebiotics consensus statement on the scope and appropriate use of the term probiotic. Nat Rev Gastroenterol Hepatol 2014; 11: 506-514.

4. Lee N-K, Kim S-Y, Han KJ, et al. Probiotic potential of Lactobacillus strains with antiallergic effects from kimchi for yogurt starters. LWT - Food Science and Technology 2014; 58: 130-134.

5. Casey PG, Casey GD, Gardiner GE, et al. Isolation and characterization of antiSalmonella lactic acid bacteria from the porcine gastrointestinal tract. Letters in Applied Microbiology 2004; 39: 431-438.

6. Singh K, Kallali B, Kumar A, et al. Probiotics: A review. Asian Pacific Journal of Tropical Biomedicine 2011; 1: S287-S290.

7. Yadav R, Shukla P. An Overview of Advanced Technologies for Selection of Probiotics and Their Expediency: A Review. Critical reviews in food science and nutrition; 57. Epub ahead of print 27 October 2015. DOI: 10.1080/10408398.2015.1108957.

8. Cammarota M, De Rosa M, Stellavato A, et al. In vitro evaluation of Lactobacillus plantarum DSMZ 12028 as a probiotic: emphasis on innate immunity. Int J Food Microbiol 2009; 135: 90-98.

9. de Vries MC, Vaughan EE, Kleerebezem M, et al. Lactobacillus plantarum-survival, functional and potential probiotic properties in the human intestinal tract. International Dairy Journal 2006; 16: 1018-1028.

10. Pot B, Felis GE, Bruyne KD, et al. The genus Lactobacillus. In: Lactic Acid Bacteria. John Wiley \& Sons, Ltd, pp. 249-353.

11. Ko JS, Yang HR, Chang JY, et al. Lactobacillus plantarum inhibits epithelial barrier dysfunction and interleukin- 8 secretion induced by tumor necrosis factor- $\alpha$. World $J$ Gastroenterol 2007; 13: 1962-1965.

12. Panigrahi $\mathrm{P}$, Parida $\mathrm{S}$, Nanda $\mathrm{NC}$, et al. A randomized synbiotic trial to prevent sepsis among infants in rural India. Nature 2017; 548: 407-412.

13. Wells JM. Immunomodulatory mechanisms of lactobacilli. Microb Cell Fact 2011; 10 Suppl 1: S17.

14. Gheziel C, Russo P, Arena MP, et al. Evaluating the Probiotic Potential of Lactobacillus plantarum Strains from Algerian Infant Feces: Towards the Design of Probiotic Starter Cultures Tailored for Developing Countries. Probiotics \& Antimicro Prot 2019; 11: 113123.

15. Dubernet S, Desmasures N, Guéguen M. A PCR-based method for identification of lactobacilli at the genus level. FEMS Microbiology Letters 2002; 214: 271-275.

16. Ren D, Li C, Qin Y, et al. In vitro evaluation of the probiotic and functional potential of Lactobacillus strains isolated from fermented food and human intestine. Anaerobe 2014; 30: $1-10$.

17. Kaushik JK, Kumar A, Duary RK, et al. Functional and Probiotic Attributes of an Indigenous Isolate of Lactobacillus plantarum. PLoS ONE 2009; 4: e8099.

18. Singh TP, Kaur G, Malik RK, et al. Characterization of Intestinal Lactobacillus reuteri Strains as Potential Probiotics. Probiotics Antimicrob Proteins 2012; 4: 47-58. 
19. Sgouras D, Maragkoudakis P, Petraki K, et al. In vitro and in vivo inhibition of Helicobacter pylori by Lactobacillus casei strain Shirota. Appl Environ Microbiol 2004; 70: 518-526.

20. Duary RK, Rajput YS, Batish VK, et al. Assessing the adhesion of putative indigenous probiotic lactobacilli to human colonic epithelial cells. Indian J Med Res 2011; 134: 664671.

21. Li C, Chen Y, Kwok L-Y, et al. Identification of potential probiotic Lactobacillus plantarum isolates with broad-spectrum antibacterialactivity. Dairy Sci \& Technol 2015; 95: 381-392.

22. Lee Y-K, Puong K-Y, Ouwehand AC, et al. Displacement of bacterial pathogens from mucus and Caco-2 cell surface by lactobacilli. J Med Microbiol 2003; 52: 925-930.

23. Tuo Y, Yu H, Ai L, et al. Aggregation and adhesion properties of 22 Lactobacillus strains. Journal of Dairy Science 2013; 96: 4252-4257.

24. Weisburg WG, Barns SM, Pelletier DA, et al. 16S ribosomal DNA amplification for phylogenetic study. J Bacteriol 1991; 173: 697-703.

25. Jiang M, Zhang F, Wan C, et al. Evaluation of probiotic properties of Lactobacillus plantarum WLPL04 isolated from human breast milk. Journal of Dairy Science 2016; 99: 1736-1746.

26. Bamola V, Sharma N, Gahlowt A, et al. A Non Invasive Technique to Assess Mucosal Immunity in Healthy Population by Measuring Immunoglobulin Receptor Expression on Viable Colonocytes. 2016. Epub ahead of print 2016. DOI: 10.4172/1948-5948.1000279.

27. Vizoso P MG, Rodriguez Gómez M, Seifert S, et al. Lactobacilli stimulate the innate immune response and modulate the TLR expression of HT29 intestinal epithelial cells in vitro. International Journal of Food Microbiology 2009; 133: 86-93.

28. Livak KJ, Schmittgen TD. Analysis of relative gene expression data using real-time quantitative PCR and the 2(-Delta Delta C(T)) Method. Methods 2001; 25: 402-408.

29. Duary RK, Batish VK, Grover S. Immunomodulatory activity of two potential probiotic strains in LPS-stimulated HT-29 cells. Genes Nutr 2014; 9: 398.

30. Salvetti E, Torriani S, Felis G. A Survey on Established and Novel Strains for Probiotic Applications. In: Foerst P, Santivarangkna C (eds) Advances in Probiotic Technology. CRC Press, pp. 26-44.

31. Liu C-J, Wang R, Gong F-M, et al. Complete genome sequences and comparative genome analysis of Lactobacillus plantarum strain 5-2 isolated from fermented soybean. Genomics 2015; 106: 404-411.

32. Salvetti E, O'Toole PW. The Genomic Basis of Lactobacilli as Health-Promoting Organisms. Microbiol Spectr; 5. Epub ahead of print 2017. DOI: 10.1128/microbiolspec.BAD-0011-2016.

33. Bezkorovainy A. Probiotics: determinants of survival and growth in the gut. Am J Clin Nutr 2001; 73: 399S-405S.

34. Burns P, Sánchez B, Vinderola G, et al. Inside the adaptation process of Lactobacillus delbrueckii subsp. lactis to bile. Int J Food Microbiol 2010; 142: 132-141.

35. Klare I, Konstabel C, Werner G, et al. Antimicrobial susceptibilities of Lactobacillus, Pediococcus and Lactococcus human isolates and cultures intended for probiotic or nutritional use. Journal of Antimicrobial Chemotherapy 2007; 59: 900-912.

36. Monteiro C, do Carmo M, Melo B, et al. In Vitro Antimicrobial Activity and Probiotic Potential of Bifidobacterium and Lactobacillus against Species of Clostridium. Nutrients 2019; 11: 448.

37. Sharma C, Gulati S, Thakur N, et al. Antibiotic sensitivity pattern of indigenous lactobacilli isolated from curd and human milk samples. 3 Biotech 2017; 7: 53. 
38. Chang YH, Kim JK, Kim HJ, et al. Selection of a potential probiotic Lactobacillus strain and subsequent in vivo studies. Antonie Van Leeuwenhoek 2001; 80: 193-199.

39. D'Aimmo MR, Modesto M, Biavati B. Antibiotic resistance of lactic acid bacteria and Bifidobacterium spp. isolated from dairy and pharmaceutical products. International journal of food microbiology 2007; 115: 35-42.

40. Sharma P, Tomar SK, Sangwan V, et al. Antibiotic Resistance of Lactobacillus sp. Isolated from Commercial Probiotic Preparations. Journal of Food Safety 2016; 36: 3851.

41. Temmerman R, Pot B, Huys G, et al. Identification and antibiotic susceptibility of bacterial isolates from probiotic products. Int J Food Microbiol 2003; 81: 1-10.

42. Coppola R, Succi M, Tremonte P, et al. Antibiotic susceptibility of Lactobacillus rhamnosus strains isolated from Parmigiano Reggiano cheese. Lait 2005; 85: 193-204.

43. Gordon MA, Graham SM, Walsh AL, et al. Epidemics of Invasive Salmonella enterica Serovar Enteritidis and S. enterica Serovar Typhimurium Infection Associated with Multidrug Resistance among Adults and Children in Malawi. Clin Infect Dis 2008; 46: 963-969.

44. Kongsanan P, Angkititrakul S, Kiddee A, et al. Spread of Antimicrobial-Resistant Salmonella from Poultry to Humans in Thailand. Jpn J Infect Dis 2021; 74: 220-227.

45. Mao Y, Zeineldin M, Usmani M, et al. Distribution and Antibiotic Resistance Profiles of Salmonella enterica in Rural Areas of North Carolina After Hurricane Florence in 2018. Geohealth 2021; 5: e2020GH000294.

46. Sargun A, Sassone-Corsi M, Zheng T, et al. Conjugation to Enterobactin and Salmochelin S4 Enhances the Antimicrobial Activity and Selectivity of $\beta$-Lactam Antibiotics against Nontyphoidal Salmonella. ACS Infect Dis 2021; 7: 1248-1259.

47. Thiennimitr P, Winter SE, Bäumler AJ. Salmonella, the host and its microbiota. Curr Opin Microbiol 2012; 15: 108-114.

48. Fransen F, Zagato E, Mazzini E, et al. BALB/c and C57BL/6 Mice Differ in Polyreactive IgA Abundance, which Impacts the Generation of Antigen-Specific IgA and Microbiota Diversity. Immunity 2015; 43: 527-540.

49. Cullender TC, Chassaing B, Janzon A, et al. Innate and adaptive immunity interact to quench microbiome flagellar motility in the gut. Cell Host Microbe 2013; 14: 571-581.

50. Gutzeit C, Magri G, Cerutti A. Intestinal IgA production and its role in host-microbe interaction. Immunol Rev 2014; 260: 76-85.

51. Mantis NJ, Rol N, Corthésy B. Secretory IgA's complex roles in immunity and mucosal homeostasis in the gut. Mucosal Immunol 2011; 4: 603-611.

52. Ulluwishewa D, Anderson RC, McNabb WC, et al. Regulation of tight junction permeability by intestinal bacteria and dietary components. J Nutr 2011; 141: 769-776.

53. Rokana N, Singh R, Mallappa RH, et al. Modulation of intestinal barrier function to ameliorate Salmonella infection in mice by oral administration of fermented milks produced with Lactobacillus plantarum MTCC 5690 - a probiotic strain of Indian gut origin. Journal of Medical Microbiology 2016; 65: 1482-1493.

54. Candela M, Perna F, Carnevali P, et al. Interaction of probiotic Lactobacillus and Bifidobacterium strains with human intestinal epithelial cells: adhesion properties, competition against enteropathogens and modulation of IL-8 production. Int J Food Microbiol 2008; 125: 286-292.

55. Maloy KJ, Kullberg MC. IL-23 and Th17 cytokines in intestinal homeostasis. Mucosal Immunol 2008; 1: 339-349.

56. Song X, He X, Li X, et al. The roles and functional mechanisms of interleukin-17 family cytokines in mucosal immunity. Cell Mol Immunol 2016; 13: 418-431. 
57. Valeri M, Raffatellu M. Cytokines IL-17 and IL-22 in the host response to infection. Pathog Dis; 74. Epub ahead of print 2016. DOI: 10.1093/femspd/ftw111.

58. Liu J, Gu Z, Song F, et al. Lactobacillus plantarum ZS2058 and Lactobacillus rhamnosus GG Use Different Mechanisms to Prevent Salmonella Infection in vivo. Front Microbiol 2019; 10: 299.

59. Bermudez-Brito M, Muñoz-Quezada S, Gómez-Llorente C, et al. Lactobacillus paracasei CNCM I-4034 and its culture supernatant modulate Salmonella-induced inflammation in a novel transwell co-culture of human intestinal-like dendritic and Caco-2 cells. BMC Microbiol; 15. Epub ahead of print 1 April 2015. DOI: 10.1186/s12866-015-0408-6.

60. Storr M, Stengel A. [Systematic review: clinical evidence of probiotics in the prevention of antibiotic-associated diarrhoea]. MMW Fortschr Med 2021; 163: 19-26.

61. Buddhasiri S, Sukjoi C, Kaewsakhorn T, et al. Anti-inflammatory Effect of Probiotic Limosilactobacillus reuteri KUB-AC5 Against Salmonella Infection in a Mouse Colitis Model. Front Microbiol 2021; 12: 716761.

62. Sassone-Corsi M, Raffatellu M. No vacancy: how beneficial microbes cooperate with immunity to provide colonization resistance to pathogens. J Immunol 2015; 194: 40814087. 